\title{
Artery Smooth Muscle Tissue
}

National Cancer Institute

\section{Source}

National Cancer Institute. Artery Smooth Muscle Tissue. NCI Thesaurus. Code C49195.

The smooth muscle tissue present in the tunica media which is the middle layer of the wall of an artery. 